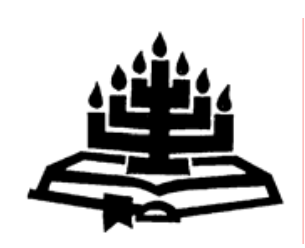

\title{
Die Dordtse tradisie en binding aan die belydenis
}

\author{
P.J. Strauss \\ Hoof: Departement Ekklesiologie \\ Fakulteit Teologie \\ Universiteit van die Vrystaat \\ BLOEMFONTEIN \\ E-pos: straussp.hum@mail.uovs.ac.za
}

\section{Abstract: \\ The church tradition of Dordt and subscription to the confessions}

A thorough analysis of history shows that the National Synod of Dordrecht (1618-1619) declared that the confessions of the church, especially the three Formulas of Unity of the Dutch Reformed Churches, have confessional authority. That indicates authority on the doctrines the confessions formulate and confess because (quia) these are according to Scriptures. This insight helped some reformed churches up to now to deal with criticism levelled against non-doctrinal issues in, for instance, the Confessio Belgica.

A case can be argued that a literal approach to the question of the authority of these confessions takes us back beyond Dordt. It ignores the history of 1618-1619, fails to get a grip on the very nature of confessions of faith or creeds and does not help to solve the problem.

\section{Opsomming}

\section{Die Dordtse tradisie en binding aan die belydenis}

'n Grondige analise van die kerkgeskiedenis toon aan dat die Nasionale Sinode van Dordrecht (1618-1619) verklaar het dat die drie Formuliere van Eenheid as belydenisskrifte vir kerke in die Nederlandse gereformeerde tradisie gesag ten opsigte van die belydenis het. Dit impliseer gesag ten opsigte van die leer wat die belydenisse verwoord en bely, omdat (quia) dit met die Skrif ooreenstem. Hierdie insig het sommige kerke sedertdien gehelp in hulle afwysing van kritiek teen nie-leerstellige aspekte van, byvoorbeeld, die Nederlandse Geloofsbelydenis. 
'n Saak kan ook daarvoor uitgemaak word dat 'n letterlike benadering van hierdie vraagstuk ons terugneem na vóór Dordt. Dit gaan aan die geskiedenis van 1618-1619 verby, mis die eie aard van belydeniskrifte en help daarom nie om die probleem op te los nie.

\section{Inleidend}

Die bekende Nasionale Sinode van Dordrecht van 1618-1619 het op sy 162ste sitting, op 16 Mei 1619, besluit op

... een accuraet formulier van onderteeckeninghe der Confessie, Catechismi, ende Synodale verclaringhe waer mede alle kerckendienaren hare overeenstemminge in de rechtgevoelende leere claerlicke betuygen, ende uytvluchten van sommighe, waermede zy de kercken pleghen te bedrieghen, voorcomen worden (Kuyper, s.a.:150).

Met die ondertekening van hierdie formulier - daar is op 'n soortgelyke formulier vir doktore in die Teologie, ander professore, rektore, skoolmeesters en sieketroosters besluit (Kuyper, s.a.:193 e.v., 202, 231, 245-247; vgl. Kruger et al., 1966:330)1 - sou die predikante verklaar én met hulle handtekening bevestig dat die belydenisskrifte van die destydse Gereformeerde Kerke in Nederland geestelike en kerkregtelike gesag dra en hulle innerlik bind (De Gier, 1989:257). Die belydenisse in geding was die Drie Formuliere van Eenheid wat as gereformeerde belydenisse deur dié Dordtse Sinode aanvaar is. Die Nederlandse Gereformeerde Kerke se formuliere van geloofs- of belydeniseenheid was, blykens die aanhaling, die Confessio Belgica of Nederlandse Geloofsbelydenis, die Heidelbergse Kategismus en die Leerreëls of Canones van Dordt (Donner \& Van den Hoorn, s.a.:325).

Waarom het die Dordtse Sinode op 'n accuraet formulier van onderteeckeninghe besluit en wat was die betekenis of implikasies daarvan? Die eerste vergadering in die breër verband van die Nederlandse Gereformeerde Kerke, die Konvent van Wesel in 1568, het immers reeds gevra dat byvoorbeeld die predikante, voordat hulle toegelaat word tot die bediening van die Woord, mondelinge instemming met sowel die Confessio Belgica as die Kategismus betuig (Pont, 1981:78 - Wesel artikel 18). Daarby het die eerste

1 Hoewel die Sinode aanvanklik ook op 'n ondertekeningsformulier vir ouderlinge en diakens besluit het, is dit later na die klasses en provinsiale sinodes verwys (Kuyper, s.a.:202, 231). 
Algemene of Nasionale Sinode in hierdie verband (Pont, 1981:92, 104; vgl. Bouwman, 1985:198), die Sinode van Emden van 1571, 'n stappie verder gegaan en op die ondertekening van dié twee formulieren van eenigheid $\mathbf{2}$ besluit. Emden wou dat die broederen ook die Franse Geloofsbelydenis van 1559 onderteken om daarmee ook hulle eendrachtigheyt of eenigheyt in geloof met die Franse gereformeerde kerke uit te druk. 'n Aksie wat hulle in omgekeerde sin ook van die Franse verwag het (Rutgers, 1889:56 - Emden artikel 2).

Vir die Dordtse Sinode was hierdie bepalings van Wesel en Emden egter kennelik nie genoeg om die destydse situasie te beredder nie. Boonop dui die uitgesproke behoefte aan 'n accuraet formulier op 'n behoefte aan 'n nadere omskrywing van die aard van hierdie binding aan die belydenis.

Dit bring ons by die drie probleemvrae wat hierdie artikel ondersoek: waarom wou die Dordtse Sinode van 1618-1619 'n addisionele akkurate ondertekeningsformulier opstel? wat was die aard van die binding aan die kerklike belydenis wat hulle daarmee beoog het? en, hoe het die situasie - dit het in drie hooflyne vertak - in enkele kerke in hierdie tradisie sedertdien ontwikkel?

\section{Waarom Dordt se ondertekeningsformulier?}

Die Dordtse ondertekeningsformulier vir predikante is op 17 Mei 1619 tydens sy 164ste sitting, aanvaar. Kort saamgevat het dit daarop neergekom dat alle predikante 'n teecken van eenicheyt inde rechtgevoelende leere moeten onderteeckenen. Soos in die geval van die belydenisse van die kerk, is die onderskrywing daarvan deur die ondertekening van die ondertekeningsformulier dus ook gesien as 'n teken van die geloofs- of belydeniseenheid van die kerk.

In die ondertekening van hierdie formulier het die predikante verclaeren dat hulle

oprechtelick in goeder conscientie voor den Heere ... van herten ghevoelen ende geloven, dat alle de articulen ende stucken der leere (beklemtoning - PJS) in [die Drie Formuliere

$2 \quad$ Formuliere van Eenheid beteken hier eenvoudig dat hierdie twee (later drie, met die Leerreëls wat in 1619 bygekom het) geskrifte, as die geformuleerde belydenisse van geloof van die Nederlandse Gereformeerde Kerke, die eenheid van hulle geloof uitdruk (vgl. Bouwman, 1985:569). 
van Eenheid] ... begrepen ... in alles met Goodts woort over een comen (Kuyper, s.a.:186-187).

Verder het hulle met hulle ondertekening belowe dat hulle hierdie voorss. leere (voornoemde of betrokke leer - PJS) naarstigtelik sal leer en voorstaan en niks direk of indirek daarteen in die openbaar of geheim sal leer nie. Hulle sal alle dwalinge wat hiermee in stryd is - in besonder die Arminianisme wat die direkte oorsaak van die Dordtse Sinode was - help afweer en weerlê. Indien hulle enige bedenkinge teenoor hierdie leer (voorss. leere) ontwikkel, sal hulle dit nóg in die geheim, nóg in die openbaar voorstaan en eers aan die kerkraad, klassis of sinode vir beoordeling voorlê. 'n Oordeel waaraan hulle hulle dan sal onderwerp. Indien hulle dit nie doen nie, stel hulle hulself bloot aan skorsing. Daarby verklaar hulle hulle ook gewillig om enige tyd, as gevolg van ghewichtighe oorsaecken en ter wille van die eenheid en suiwerheid van die leere, beskikbaar te wees om navrae van hierdie vergaderings oor aspekte van hulle naerder gevoelen ende verclaringhe van die leer, te beantwoord (Kuyper, s.a.:186-188).

Voorlopig beskou en slegs op die teks af, het die binding volgens hierdie formulier dus gegaan om 'n binding aan die leer soos begrepe of vervat in die Drie Formuliere van Eenheid. Daarmee is beslis nader inhoud gegee aan die blote ondertekening van die belydenisskrifte soos by Emden. Op die vraag, wat presies die Sinode van Dordtrecht hiermee bedoel het, word later teruggekom. 3

Die opdrag vir die opstel van die ondertekeningsformulier is op 16 Mei 1619 aan 'n kommissie gegee wat uit een afgevaardigde elk van Groningen, Gelderland, Suid-Holland en Zeeland bestaan het (Kuyper, s.a.:166). Anders as wat normaalweg in so 'n gewigtige saak verwag kon word, was hulle rapport reeds die volgende dag gereed vir die Sinode. ' $n$ Situasie wat alleen verklaarbaar is vanuit die historiese verloop wat die saak tot op daardie stadium gehad het.

Die Dordtse ondertekeningsformulier van 1619 was nie die eerste van sy soort in die Nederlandse Gereformeerde Kerke nie. Na

3 Behalwe weerstand op die Dordtse Sinode van 1618-1619 self teen die formulering van sommige van die beloftes - spesifiek dat twyfel of dubia oor leerstukke aan die kerkraad, klassis of sinode voorgelê moet word - was daar later ook weerstand in Friesland, Holland en Zeeland. Dit is te betwyfel of die Dordtse ondertekeningsformulier ooit in Friesland gebruik is. Die besware het egter nie oor binding aan die belydenis gegaan nie (Kuyper, s.a.:200-201). 
Emden het opeenvolgende sinodes die Emdense bepaling van die ondertekening van die belydenisse oorgeneem. Dit is deurgaans slegs van toepassing gemaak op persone wat in die besondere ampte of dienste sou staan. Van ander gemeentelede is net verwag om dit voor hulle toelating tot die Nagmaal te doen. Die Nasionale Sinode van Den Haag van 1586 het egter 'n tree verder gegee en tugmaatreëls ingestel vir 'n weiering om die belydenisse te onderskryf en te onderteken. So iets kon tot 'n predikant se skorsing en eventuele afsetting lei (Rutgers, 1889:498 - Den Haag, artikel 47). Teen hierdie tyd het persone soos Coolhaas, Herbert en Hakkius selfs vanaf die kansel teen sommige artikels te velde getrek (Bouwman, 1985:568; Pont, 1981:161).

Hoe die belydenisskrifte ná Emden onderteken is, het van plek tot plek verskil. In sommige plekke is dit bloot onderteken, terwyl daar op ander plekke van 'n kort formule gebruik gemaak is om dit te doen. In die ou Belydenisboek van 1589 van Klassis Enkhuizen kom daar so ' $n$ formule voor waarmee die ondertekenaar die belydenis ag as gegrond op God se Woord en belowe om niks te leer wat daarmee in stryd is nie.

As gevolg van die verhewiging van die stryd teen die Remonstrante of Arminiane in die laat sestiende eeu, is die behoefte aan 'n ondertekeningsformulier wat sekere sake duideliker uitspel, al hoe sterker gevoel (Van Dellen \& Monsma, 1967:39). Hoewel Remonstrantse predikante die Twee Formuliere van Eenheid onderteken het, het hulle probleme met sekere aspekte van die gereformeerde leer nogtans nie daarmee verdwyn nie (De Gier, 1989:259). 4 Benewens hulle besware teen dele van die Confessio Belgica en die Kategismus, het sommige Arminiane gestuit op die feit van die kerke se aanvaarding van die Twee Formuliere van Eenheid én laasgenoemde se vasbeslotenheid om dit met of sonder die steun van die Nederlandse staatsowerheid te handhaaf (Bouwman, 1985:569; Pont, 1981:173; Spoelstra, 1989:299).

Hoe ernstig sommige Nederlandse gereformeerdes destyds was oor die waarheid van hulle belydenisse, blyk byvoorbeeld uit 'n brief in 1574 van Caspar van der Heyden, die bekende predikant van Middelburg en voorsitter van die Algemene Sinode van Emden in

$4 \quad$ Spoelstra (1989:299) betoog dat 'n blote ondertekening van die belydenis nog altyd die ruimte laat dat dit nie quia (omdat dit met die Heilige Skrif ooreenkom) nie, maar quatenus (in soverre as wat dit met die Skrif ooreenkom) onderteken word. 
1571 en die Provinsiale Sinode van Dordrecht in 1574 (Pont, 1981:95 e.v.). Van der Heyden skryf na aanleiding daarvan dat ouderlinge en diakens in Delft geweier het om die konfessies te onderteken. Vir hom is dit onvergeeflik dat dié persone weier om die belydenis met ink te onderskryf, terwyl ander gereformeerdes bereid is om dit met hulle bloed te verseël (Bouwman, 1985:568). Die opsteller van die Confessio Belgica in 1561 in sy oorspronklike vorm, Guido de Brés, sou dit in 1567 met sy galgdood doen (Van Bruggen, 1971:13). Die biograaf van die outeurs, Van der Heyden en Van Lennep, word instemmend deur Bouwman (1985:568) aangehaal:

Het was een van harte instemmen met de eeuwige waarheden, die daarin werden geleerd (beklemtoning - PJS), en een verklaren tevens, dat men bereid was die waarheid met zijn bloed te bezegelen, iets wat in die dagen waarlijk geen ijdele klank was. 5

Die oudste ondertekeningsformulier vir predikante is dié wat die Klassis Alkmaar op 21 September 1608 opgestel het. H.H. Kuyper (s.a.:194) noem dit die moederformulier van alle ondertekeningsformuliere. 6 In hierdie formulier word daar ook verwys na die leere soos vervat of begrepe in die Confessio Belgica en die Kategismus. Alkmaar verklaar in sy formulier dat dié leer ooreenkom met die Woord van God en sodoende met die fondament van die leer van die saligheid. Daarom moet sy predikante beloof om dit te onderhou en alles wat daarmee stry, vlytig te verwerp. Sowel hierdie verklaring as die belofte kom later in die Dordtse ondertekeningsformulier tereg. Aan die begin van 1610 volg die Klassis Buren met 'n ondertekeningsformulier waarin dieselfde verklaring en belofte ook opgeneem word en die kettery van die Arminianisme by die naam genoem word (Bouwman, 1985:570; Jansen, 1952:236). Enkele vrae wat ook later in die Dordtse formulier weerspieël word, word deur Buren saam met sy formulier gevra, naamlik of die kandidaat met 'n goeie gewete op die vrae by sy toelatingseksamen kon antwoord; of hy enige twyfel wat hy in die toekoms oor enige

$5 \quad$ Bouwman (1912:184) wys ook daarop dat die Nederlandse Geloofsbelydenis in die 1560's by uitstek as die bindende faktor van die Nederlandse Gereformeerde Kerke beskou is (vgl. Rutgers, s.a.:340) en dat die aanvanklike opstellers (ondertekenaars? - PJS) daarvan bereid was om dit met hulle bloed te verseël.

6 Bouwman (1985:570) neem hierdie uitdrukking van H.H. Kuyper oor sonder enige verwysing na of erkenning van laasgenoemde. 
leerstuk ontwikkel, sonder verwyl by die klassis aanhangig sal maak, en; of hy homself sal onttrek aan die kerkdiens as die klassis hom nie gelyk gee nie. ${ }^{7}$

In Mei 1610 kom die Provinsiale Sinode van Zeeland met 'n ondertekeningsformulier waarin die belangrikste elemente van Alkmaar en Buren opgeneem is én waarin die predikante belowe om gewillig te wees om te antwoord indien die klassis dit nodig ag om 'n nadere verklaring oor enig stuk der leer by hulle te neem. Soos reeds gesien, vind ook hierdie element sy weg na die Dordtse ondertekeningsformulier. In 1612 stel die Provinsiale Sinode van Gelderland 'n ondertekeningsformulier op waarin dié van Alkmaar en Zeeland as leidrade gebruik word (Jansen, 1952:236). Gelderland reageer op die optrede van Vorstius en ander Remonstrante (Bouwman, 1985:572).

Dit is teen hierdie agtergrond dat die Provinsiale Sinode van SuidHolland van 1618 die Nasionale Sinode van 1618-1619 versoek het om 'n ondertekeningsformulier vir predikante daar te stel (Kuyper, s.a.:133). Die versoek is deur Suid-Holland se eie konsepformulier vergesel. Hierby het die Provinsiale Sinode van Overijssel voorgestel dat alle predikante, professore, rektore, skoolmeesters, ouderlinge en diakens die belydenisse onderteken (Kuyper, s.a.:444-445). Wat Dordt oor albei sake besluit het, is reeds aangetoon.

Behalwe dat hierdie historiese oorsig lig werp op die rede vir die opstelling van die ondertekeningsformulier, plaas dit 'n aantal ander sake in perspektief.

- Eerstens is die kommissie wat die saak moes voorberei, saamgestel uit verteenwoordigers van die provinsiale sinodes wat hulle alreeds oor die saak uitgelaat het. Die enkele uitsondering hierop was die verteenwoordiger van Groningen.

- Tweedens het die goedgekeurde Dordtse formulier al die elemente van Zeeland, Gelderland en Alkmaar in homself

$7 \quad$ Hierdie elemente oor die bekendmaak van twyfel oor leerstukke en die blootstelling aan skorsing is skynbaar ontleen aan artikel 47 van die Kerkorde van Den Haag (1586), wat juis vir tugmaatreëls in geval van 'n weiering om die konfessies te teken, voorsiening gemaak het (vgl. Pont, 1981:161). 
opgeneem en daarmee 'n samevatting (compendium) van die bestaande formuliere geword (Kuyper, s.a.:196 e.v.). ${ }^{8}$

- Derdens was daar 'n sigbare, groeiende konsensus in die Nederlandse Gereformeerde Kerke rondom die behoefte aan so 'n formulier en die soort sake wat daarin opgeneem moes word. Hierdie konsensus het oor 'n tydperk van meer as tien jaar vorm aangeneem. Dit was dus nie 'n nuwe saak nie en die kommissie moes slegs die bestaande gedagtes verwoord en in een formulier saamvat. Daarom dat die saak op die Dordtse Sinode van 16181619 binne twee dae afgehandel is.

Wat uit hierdie historiese relaas egter nie duidelik blyk nie, is wat, volgens Dordt, die inhoud van die binding aan die belydenisskrifte was. Wat is bedoel met die leer soos vervat of begrepe in die Drie Formuliere van Eenheid wat in alles met die Skrif ooreenkom en dus - na oortuiging - met afgeleide Skrifgesag beklee is? Dié leer waarvoor beskrywings soos rechtgevoelende leer en selfs eeuwige waarheden gebruik is? Daarby, as dit hier gaan om 'n leer wat vervat is in die Drie Formuliere van Eenheid: wat was die Sinode se visie op die verhouding tussen die inhoud en vorm wat hierdie geskrifte betref?

Die antwoorde hierop word vanuit 'n historiese en 'n tetiese perspektief benader.

\section{Dordt en die inhoud van die binding aan die belydenis}

'n Aanduiding van watter waarhede volgens Dordt betrekking het op die leer, soos vervat in die Drie Formuliere van Eenheid, blyk uit die Sinode se hantering van die goedkeuring (of bekragtiging - PJS) ${ }^{9}$ van die Confessio Belgica en die Kategismus. Die goedkeuring van die Konfessie vind op 30 April 1619 en dié van die Kategismus op 1 Mei 1619 plaas (vgl. Donner \& Van den Hoorn, s.a.: 307 e.v., 320,

$8 \quad$ H.H. Kuyper het in sy De Post Acta of Nahandelingen van de Nationale Synode van Dordrecht in 1618 en 1619 gehouden belangrike grondwerk ten opsigte van die ontstaan en bewoording van die Dordtse ondertekeningsformulier gedoen. Vanaf p. 196 plaas hy - in 'n teksvergelyking - die formuliere van Zeeland, Gelderland en Dordt langs mekaar.

9 H.H. Kuyper (s.a.:324) wys ook daarop dat die oorweging en eventuele goedkeuring plaasgevind het op versoek van die Nederlandse Regering of State Generaal. lets waartoe die Sinode waarskynlik nie bereid sou gewees het nie as veranderinge aan die Formuliere die oogmerk of die versoek was. 
325). Dit geskied in albei gevalle met die eenparige steun van die 23 buitelandse teoloë en die "binnelandse" afgevaardigdes, wat uit 37 predikante en 19 ouderlinge bestaan. Die buitelanders kom uit Engeland, Switserland en Duitsland. Sommige Duitse en al die Franse genooides was verhinder om te kom (Kuiper, 1995:268).

Die direkte aanleiding vir die hantering van die saak deur die Sinode was die versoek van die voorsitter van die 18 kommissarisse-politiek op die Sinode, Marthinus Gregorii, namens die Nederlandse State Generaal - die versoek, naamlik dat die vergadering saam met die buitelandse afgevaardigdes die Confessio Belgica en die Kategismus opnuut moet toets om vas te stel of dit ooreenstem met die waarheid soos in die Heilige Skrif en die belydenisskrifte van ander kerke, geleer word. Volgens die kommissaris behoort hierdie ondersoek alleen te loopen over de dogmata en de essentia doctrinae en niet over de methode of phraseologie.10 Die binnelanders sou na die vertrek van die buitelanders daaraan aandag gee. Die voorsitter van die Sinode, Johannes Bogerman, wat vooraf met die kommissarisse in gesprek was oor die versoek, beklemtoon dit ook dat die afgevaardigdes nie op die teks nie, maar op die leerinhoud van die Konfessie moet let - die Confessio Belgica, wat tydens bittere vervolging geskryf en met die bloed van die martelare verseël is. ' $n$ Belydenis wat volgens hom nog nooit ten opsigte van sy getrouheid aan die Skrif bevraagteken is nie en eenparig deur die Nederlandse Gereformeerde Kerke aanvaar is (Kuyper, s.a.:323-326). In die notule van die sinodeverrigtinge op 6 Mei 1619 en in dieselfde trant word die goedkeuring of bekragtiging van sowel die Confessio Belgica as die Kategismus op respektiewelik 30 April en 1 Mei andermaal omskryf as 'n goedkeuring van de leer in de Belijdenis en den Cathechismus dezer Kerken begrepen (Donner \& Van den Hoorn, s.a.:325).

\subsection{Onderskeid tussen saak en formulering}

Wat skerp opval in hierdie benadering van die Sinode, is die onderskeid tussen die leer en die teks waarmee hierdie leer verwoord word. Hierdie onderskeid word selfs ook geïmpliseer in die geykte frase "die leer soos vervat of begrepe in" wat in die notule sowel as die ondertekeningsformulier van die Sinode gebruik word.

10 Calvyn handhaaf in sy Institusie (Boek IV,I,12) ook die onderskeid tussen essensiële of hoofsake en middelmatige sake van die geloof. Volgens hom behoort verskille oor laasgenoemde nie die eenheid van die kerk in gedrang te bring nie (Sizoo, s.a.: IV, 21). 
'n Mens sou dit kon waag om te beweer dat die "heilige belydeniswaarhede" waarvoor mense hulle bloed sou stort of die regsinnige leer, soos gebaseer op die waarhede van die Bybel oor God, sonde, verlossing en dankbaarheid, ${ }^{11}$ alles dinge wat hier ter sprake is, geïntegreer, maar nie identies is met die teks waarin dit verpak is nie. Van hierdie gereformeerdes sou hulle bloed gee vir die waarheid en krag van die essentia doctrinae van hulle belydenisse, maar nie vir die fraseologie daarvan nie. Dit het gegaan om die belydenis van hulle geloof, nie om die geloof in hulle belydenis nie (Veenhof, 1969:220)!12

Dit wil dus hieruit voorkom asof die Dordtse tradisie ten opsigte van binding aan die belydenis, in ooreenstemming was met die Franse Sinode van La Rochelle in 1607. Volgens La Rochelle - wat waarskynlik met die tweelingboetie van die Confessio Belgica, naamlik die Confessio Gallicana van 1559 gewerk het - het die belydenis alleen krag en gesag in dít wat dit bely (Polman, s.a.:87). Moontlik in reaksie op dié twee voorbeelde en ter ondersteuning van dieselfde standpunt, het die bekende gereformeerde kanonikus, G. Voetius (1663:775), later betoog dat "oneffenhede"13 in die Nederlandse Geloofsbelydenis, soos dat Paulus die Brief aan die Hebreërs geskryf het (artikel 4) of dat Judas Iskariot die sakrament van die Nagmaal ontvang het (artikel 35) in die Galliese en Nederlandse kerke nie met dieselfde gesag beklee is as die "artikels" (geloofstukke? - PJS) van hierdie belydenis nie.

Die Dordtse Sinode van 1618-1619 het binding aan die belydenis hanteer asof daar, in die woorde van Jonker (1994:155) "'n sekere speelruimte" tussen saak en formulering is. Dit is daarom dat die

11 Volgens Jonker $(1994: 16,21)$ het die belydenisskrifte van die Reformasie gekonsentreer op die soteriologie, omdat die destydse breuk met Rome juis op hierdie punt gelê het.

12 Veenhof (1969:220) voer aan dat die lewende, blye geloof van die Reformatore van die sestiende eeu ná die "Dordtse periode" oorgegaan in die strakke ortodoksie van die sewentiende eeu. Dit het vir hulle nie meer gegaan om 'n belydenis van hulle geloof nie, maar 'n geloof in hulle belydenis. Hierdie ortodoksie het die weg voorberei vir die rasionalisme wat die Christelike geloof verwring het tot 'n saak van die verstand: 'n saak van historiese en redelike bewysvoerings waarin geloofsekerheid verwar is met redelike insig. Die rasionalisme, soos gedra deur die Verligting (vanaf ongeveer 1650), is 'n radikale konsekwensie of uitloper van die Renaissance (ongeveer 1350-1500) en is juis vir meer as 'n eeu teruggehou deur die Reformasie. 
hele Sinode die Confessio Belgica bekragtig het, maar die finale vasstelling van die teks aan die binnelandse afgevaardigdes oorgelaat het. In hierdie proses van bekragtiging is die teks van die Harmonia Confessionum van die Frankfurtse Konvent van 1577 gebruik - nie alleen omdat dit in Latyn as die meer algemene gebruikstaal van destyds was nie, maar ook omdat dit die mees bekende teks in die geheele Christelijke wereld van daardie dae was. Tog het Dordt later, op 24 Mei 1619, sy eie Franse en Nederlandse uitgawes van hierdie belydenis, wat in hoofsaak gebaseer is op die oudste beskikbare tekste daarvan, goedgekeur (Kuyper, s.a.:340-346).14 Dit is onseker watter teks van die Kategismus deur die Sinode in die proses van bekragtiging gebruik is (Van Itterzon, 1971:75). Die vergadering het die teks van hierdie belydenis ook nie hersien of 'n eie weergawe daarvan aanvaar nie (Kuyper, s.a.:337).

Dieselfde "speelruimte" is waar te neem by Emden se besluit oor die Heidelbergse Kategismus. In artikel 5 bepaal hierdie Sinode dat die Franssprekendes Calvyn se Geneefse Kategismus en die Nederlandssprekendes die Heidelbergse Kategismus van Ursinus en ander sal gebruik. Ander forme van kategismusse kan ook gebruik word, op voorwaarde dat dit met die Woord van God ooreenkom (Rutgers, 1889:57-58).

\subsection{Steeds 'n verband tussen inhoud en vorm}

Hierdie "speelruimte" beteken egter nie dat die noue verband tussen inhoud en vorm of saak en formulering in die Dordtse tradisie prysgegee is nie. Deur hulle ervaring van die dwaling deur die jare heen, het die besef onder eksponente van hierdie tradisie gegroei dat weerstand teen sekere formulerings in die teks dikwels net as kamoeflering vir ernstige dwalinge of verskille gebruik word. Daarom het daar teen 1618 die wyd gevoelde behoefte bestaan aan 'n accuraet ondertekeningsformulier by die instemming met die belydenisskrifte. Sake moes eenvoudig nader omskryf en vasgevat word. Dit bring Polman (s.a.:86-87) tot die slotsom dat Dordt vir 'n letterlike binding aan die belydenis gekies het, sonder dat de vaders daarmee muggenzifters geword het of hulle tot letterknegtery

14 Dit is bekend dat die oorspronklike Franse teks van 1561 dié van Guido de Brés en die eerste Nederlandse vertaling daarvan in 1562, herhaaldelik op opeenvolgende sinodes hersien is (Kuyper, s.a.:347 e.v.). Hierdie toedrag van sake beklemtoon die bestaan van 'n sekere speelruimte tussen saak en formulering by destydse gereformeerdes. 
gewend het. Saak en formulering moes mekaar volledig dek, maar nie so dat die belydenisskrifte in notariële aktes verander is waarin selfs die kleinste woordwysiginge strafbaar kon word nie. Dié saak het nie bestaan uit elke gebruik van 'n Bybelteks of elke frasering of verwysing nie, maar uit dit wat as geloof bely is. Die belydenisse is as geskrifte beskou wat gesag het in hulle formulering van die Bybels-Christelike geloof. Na hulle aard was hulle immers bedoel om belydenisse van die kernsake van hierdie geloof te wees (Heyns, 1992:17).

Die Dordtse tradisie het dus bepaal dat die Drie Formuliere van Eenheid gesag het in hulle geloofsleer of in dit wat hulle as geloof bely omdat (quia) dit in alles met die Skrif ooreenkom. Aan dié leer of belydenis wou die ondertekeningsformulier sy ondertekenaars bind. Nie bloot uiterlik en kerkregtelik nie, maar veral omdat dit as norma normata of tweede norm met die Skrif, as norma normans of eerste norm, ooreenkom én hulle as belydenis uit die hart gegryp was; ewige kernwaarhede wat óf die lewe óf die dood vir die mens beteken en waarvoor die belyers daarvan hulle lewe sou gee; waarhede wat eerstens geglo en dáárom verkies en verwoord is, maar met 'n keuse wat op 'n veel dieper vlak lê as die keuse van die woorde wat dit verwoord.

In dieselfde tradisie voer die gevierde gereformeerde dogmatikus, $\mathrm{H}$. Bavinck, aan dat belydenisskrifte in die kerk 'n noodsaaklikheid is, maar hóógstens as norma normata. Hulle is nie naas of bo nie, maar diep onder die Woord. Wat hom betref is hulle feilbare mensewerk en 'n onvolkome uitdrukking van dit

... wat de kerk uit de Schrift als Goddelijke waarheid in haar bewustzijn opgenomen heeft en thans op gezag van Gods woord tegenover alle dwaling en leugen belijdt.

Nogtans, aldus Bavinck, is die kerk nie 'n debatsvereniging waarin dit wat gister die leuen was, vandag skielik die waarheid is nie. So vinnig wysigbaar of relatief moet belydenisskrifte nie wees nie, omdat dit die roeping van die kerk is om 'n pilaar of rots van vastigheid ten opsigte van die Goddellike waarhede te wees (Bavinck, 1967:401-402). Bavinck tref dus ook 'n onderskeid tussen saak en formulering, met die gesag van Gods Woord agter dít wat die kerk bely.

Wat is die implikasies van hierdie soort binding aan die belydenisskrifte vir leertug? Bouwman, 'n voorstander van vryheid in gebondenheid aan die belydenis, beroep hom hierin gedeeltelik op 
Calvyn (Sizoo, s.a.:21-22). Volgens Bouwman (en Calvyn) dra leerstukke nie almal dieselfde gewig nie, sodat afwyking van 'n leerstuk per se nie noodwendig tot kerklike tug moet of sal lei nie (Bouwman, 1912:195-196). Jansen (1952:311) volg Voetius as hy 'n tugwaardige leerafwyking omskryf as 'n daad wat openbare aanstoot gee en waarin volhard word. Selfs leer- of belydenisafwykings moet aan hierdie maatstaf voldoen. Sadler (1979:63) bevind hom prinsipieel op dieselfde plek. Volgens hom is 'n tugwaardige sonde 'n ergerlike sonde, en daarom moet amptelike leertug handel oor die fundamentele sake van die geloof. Sonder om op die meriete van al hierdie standpunte oor leertug in te gaan, illustreer hierdie opmerkings die punt dat daar in die belydenisskrifte ook hoofsake en bysake of kernkwessies en middelmatige kwessies kan wees. Geen geval is aan my bekend waar iemand wat byvoorbeeld ontken dat Paulus die Brief aan die Hebreërs geskryf het, in die Dordtse tradisie van leerdwaling aangekla is nie. As hierdie waarneming water hou, bevestig dit die oortuiging, dat binding aan die belydenisskrifte in hierdie tradisie oor die leerinhoud gaan of dit wat volgens die Skrif bely word.

Dit laat ons met die laaste vraag: Hoe is hierdie tradisie in kerke wat een of ander historiese verbintenis met die Dordtse tradisie het, vertolk en toegepas?

\section{Verwikkelinge sedert Dordt (1618-1619)}

Dit wil voorkom asof daar sedert 1619 drie hoofrigtings voorkom ten opsigte van binding aan die belydenisskrifte deur teoloë en kerke wat breedweg as deel van die historiese nageslag van Dordt kan deurgaan.

- Die eerste is daardie teoloë en kerke wat klaarblyklik geen onderskeid of "speelruimte" tussen saak en formulering toelaat nie en wat op 'n byna letterlike of meganiese vertolking van die quia-standpunt staan.

- Die tweede is daardie groep wat hierdie onderskeid gekwalifiseerd handhaaf en daarvan oortuig is dat hulle steeds soos Dordt self - op die quia-standpunt staan.

- Die derde kan breedweg as die quatenus-standpunt bestempel word. By diégene het binding aan die belydenis vir alle praktiese doeleindes verdwyn, sodat hulle slegs met groot moeite daarop sal kan aanspraak maak dat hulle die Dordtse tradisie voortsit. 
Onder die eerste groep is daar Jansen, Kruger et al, Spoelstra en waarskynlik ook talle gereformeerde kerke. Dit gaan hier veral om dít waaroor hulle swyg.

In sy verwysing na die inhoud van die Dordtse ondertekeningsformulier, laat Kruger et al van die Gereformeerde Kerke in Suid-Afrika selfs die sinsnede "leer soos vervat in" weg. Wat hom betref, verklaar die ondertekenaar dat die Drie Formuliere van Eenheid in alles met die Woord van God ooreenkom. Sonder om enige blyke van 'n moontlike onderskeid tussen leer en formulering te gee, gebruik hy die uitdrukking "suiwere leer" vir die gestewel en gespoorde Drie Formuliere (Kruger et al., 1966:333). Uit dieselfde kerk gebruik Spoelstra (1989:299) ook hierdie omskrywing. Hiermee beweeg hulle in die bekende geselskap van die Nederlandse gereformeerde Jansen wat vroeër in dieselfde trant op die Dordtse ondertekeningsformulier kommentaar lewer (Jansen, 1952:237).

Die probleem by hierdie skrywers is oënskynlik simptomaties van die probleem by baie kerke in die Dordtse tradisie. Hulle bespreek of hanteer nie die probleem van die "oneffenhede" waarop Bavinck wys nie, omdat hulle dit óf ontken óf eenvoudig daaraan verbygaan. Daarmee beredder hulle nie die probleem nie (Polman, s.a.:88) en kommunikeer hulle byna iets van 'n meganiese gesag by die Drie Formuliere van Eenheid. Boonop mis hulle die eintlike punt rondom die werklike inhoud van die binding aan die belydeniskrifte in die Dordtse tradisie. Hulle kom nie by die doel en betekenis van die aanvaarde accuraet formulier van 1619 uit nie, hoe goed bedoel of lofwaardig hulle gehegtheid aan die kosbare Drie Formuliere ook al mag wees. In historiese perspektief geplaas, is hulle terug in die situasie van die Nederlandse Gereformeerde Kerke van ná Emden 1571, maar vóór Dordt 1619.

Onder die tweede groep is daar veral die Christian Reformed Church in North America en die Nederduitse Gereformeerde Kerk. Albei van hulle het intussen probeer om 'n nadere omskrywing van die "leer soos vervat in die Drie Formuliere" te gee. Daarmee het hulle nie net in die verlengde van die Dordtse tradisie beweeg nie, maar ook gereageer op die kwessie van die "oneffenhede" wat hom steeds voordoen. Wat meer is, daarmee het hulle dieselfde weg ingeslaan as die Partikuliere Sinode van Delft van 1618, wat in die hitte van die destydse stryd verklaar het dat die Confessio Belgica verstaan moet word na die sin der kercken. Delft se probleem sindsdien was egter dat "die kerke" meestal in gebreke gebly het om hierdie "sin" te omskryf (Polman, s.a.:88). 
Die Sinode van die Christian Reformed Church stel dit in 1976 in 'n bylae tot artikel 5 van sy Kerkorde, dat 'n persoon wat die ondertekeningsformulier teken, verklaar dat al die leerstukke soos vervat in die belydenisskrifte van hierdie kerk in die Woord van God geleer word. Daarmee, aldus die bylae, verklaar so 'n persoon egter nie dat al dié leerstukke op die bes moontlike manier geformuleer is of dat hierdie geskrifte alles bevat wat die Skrif leer of verwerp nie. 'n Ondertekenaar word alleen gebind aan die "doctrines which are confessed" en nie aan verwysings, sinspelings en opmerkings wat "toevallig" (incidental) met die formulering daarvan gepaard gegaan het, of die teologiese gevolgtrekkings wat sommige teoloë daaruit maak nie. Slegs die vergaderings van die kerk kan 'n nadere uitleg van die belydenis gee. Die Sinode voeg die bylae tot die Kerkorde by na aanleiding van gravamina, waaruit dit duidelik blyk dat "oneffenhede" hier ter sprake was (Engelhard \& Hofman, 2001:5051). Op sy manier bly die Christian Reformed Church hiermee in die Dordtse tradisie en op die quia-standpunt.

In dieselfde trant gee die Algemene Sinode van die Nederduitse Gereformeerde Kerk van 1998 ook na aanleiding van "oneffenhede", 'n nadere verduideliking van dit wat die binding aan die kerk se belydenisskrifte beteken. Volgens dié Sinode lê die gesag van die geskrifte in hulle verwoording van die "gereformeerde geloofsoortuiging". Hulle is hierin gesagvol omdat (quia) hulle hierin met die Skrif ooreenstem. Hulle het gesag in die "saak wat hulle volgens die Skrif wil bely"; in hulle verwoording van geloofsoortuigings, wat volgens hulle "Skriftuurlike bedoeling" vertolk moet word (NGK, 1998:414-415). Hoewel die Nederduitse Gereformeerde standpunt hiermee - in teenstelling met die van die Christian Reformed Church - niks konkreets bevat oor dit waarin die belydenisskrifte nié gesag het nie, beweeg hulle op dieselfde vlak. Die Nederduitse Gereformeerde Kerk bly Dordts en op die quia-standpunt.

Min of meer in dieselfde tyd besluit die Nederduitse Gereformeerde Kerk ook op 'n meer eietydse bewoording van sy ondertekeningsformulier, of soos dit genoem word, "plegtige" legitimasie-verklaring. Hierin verklaar 'n persoon dat hy/sy glo dat die leer "soos vervat" in die drie algemene belydenisskrifte, te wete die Apostolicum, die Belydenisse van Nicea en Athanasius én in die Drie Formuliere van Eenheid, "ooreenkom met die Woord van God". Hoewel meer eietyds, bly die strekking sowel as baie van die uitdrukkings, Dordts. So ook enkele van die beloftes wat hierop volg: dat hy/sy hierdie leer getrou sal verkondig en uitleef; alle dwalinge wat hiermee in stryd is, sal weerlê en uit die kerk probeer weer; en geen twyfel of 
ander insig daaroor sal leer of bevorder voordat hy/sy dit nie aan 'n bevoegde kerkvergadering vir beslissing voorgelê het nie (NGK, 2004:73). In één opsig is hierdie verklaring dalk sterker as dié van Dordt: 'n persoon verklaar nie dat die belydenisse ooreenkom met die Woord van God nie, maar gló dit. Beter gestel: die ondertekenaar verklaar dat hy dit glo.

Onder die derde groep is die belangrikste die Protestantse Kerk in Nederland wat in 2004 uit die Nederlandse Hervormde Kerk, die Gereformeerde Kerke in Nederland en die Evangelies Lutherse Kerk gevorm het (PKN, 2003:189). Op voetspoor van die Hervormde Kerk (Van den Heuvel, 1991:151) word hier by die erkenning van die belydenis - in die lig van die Dordtse tradisie - van 'n totaal nuwe sinsnede gebruik gemaak. In artikel 1 van sy Kerkorde voer die Protestantse Kerk aan dat hy bely in gemeenschap met die belydenis van die voorgeslagte, soos verwoord in die drie algemene belydenisse, plus twee Lutherse en vier gereformeerde belydenisskrifte uit die sestiende eeu. Deur middel van hierdie belydenisskrifte "weet" hierdie kerk sig verbonde aan die algemene Christelike kerk, die Lutherse en die gereformeerde tradisie (PKN, 2003:9). Van den Heuvel (1991:151) toon aan dat die Generale Sinode van die Hervormde Kerk vroeër verklaar het dat die frase "in gemeenschap met" wel "in overeenstemming met" kan impliseer, mits dit hier gaan om 'n binding deur die getuienis van die Heilige Gees aan die "religie van die belijdenis". Hoe dit egter ook al gedraai of verwoord word, die quia is weg, Dordt is byna vergete en belydenisvryheid is in. Op sy meeste - dit wil sê as die Protestantse Kerk die vroeëre besluit van die Hervormde Kerk vir sy rekening wil neem - gaan dit hier om ' $n$ binding aan ' $n$ vae begrip soos die religie van belydenisse uit verskillende tradisies; om quatenus in 'n eietydse baadjie.

\section{Slot}

'n Ondersoek na die geskiedenis, inhoud en toepassing van die binding aan die kerk se belydenisskrifte in die Dordtse gereformeerde tradisie lewer op sommige punte verrassende resultate op. Vir Dordt gaan dit primêr om die belydenis van die gereformeerde of Christelike geloof, nie om geloof in die kerklike belydenis nie. Volgens hierdie tradisie setel die gesag van en die binding aan die belydenisskrifte in die leer of geloofsoortuigings wat dié geskrifte bely, omdat (quia) dit ooreenkom met die Heilige Skrif. Dit gaan vir Dordt oor die leer of belydenis soos vervat en verwoord in die belydenisskrifte, en nie oor elke frase of lettertjie in die teks 
nie. Hierdie belydenis sou sommige gereformeerdes in die sestiende eeu met ink onderskryf en, as dit moet, met hulle bloed verseël.

Daarmee het die groot Nasionale Sinode van Dordrecht van 16181619 deurgesny na die prinsipiële aard van kerklike belydenisskrifte, en kerke in hierdie tradisie van 'n instrument voorsien om te handel met die "oneffenhede" wat sommige teoloë in byvoorbeeld in die Confessio Belgica aantref. Daarmee het Dordt egter ook die swaard getrek vir twee vernietigende uitwasse: konfessionalisme en liberalisme. Konfessionalisme wat die belydenis bykans meganiesletterlik in sy gesag en uitleg vertolk en dit boonop gevaarlik naby aan die Skrif, en dus onfeilbaar, plaas; Liberalisme wat wegskram van belydenisbinding en dit aan 'n humanistiese reg op vrye meningsuiting opoffer. Albei verskynsels is vandag steeds lewend en met ons (Heyns, 1992:22-24).

\section{Geraadpleegde bronne}

BAVINCK, H 1911. Modernisme en orthodoxie. Kampen: Kok.

BAVINCK, H. 1967. Gereformeerde dogmatiek IV. 5e onveranderde druk. Kampen: Kok.

BOUWMAN, H. 1912. De kerkelijke tucht. Kampen: Kok.

BOUWMAN, H. 1985. Gereformeerd kerkrecht. II. 3e onveranderde druk. Kampen: De Groot Goudriaan.

DE GIER, K. 1989. De Dordtse Kerkorde. Houten: De Hartog.

DONNER, J.H. \& VAN DEN HOORN, S.A. s.a. Acta Nationale Synode te Dordrecht. Leiden: Donner.

ENGELHARD, D.H. \& HOFMAN, L.J. 2001. Manual of Christian reformed church government. Grand Rapids: CRC.

HEYNS, J.A. 1992. Inleiding tot die dogmatiek. Halfway House: NG Kerkboekhandel.

JANSEN, J. 1952. Korte verklaring van de kerkorde van de Gereformeerde Kerken. Kampen: Kok.

JONKER, W.D. 1994. Bevrydende waarheid. Wellington: Hugenote-Uitgewers.

KRUGER, L.S. et al. 1966. Handleiding by die kerkorde van die Gereformeerde Kerke in Suid-Afrika. Potchefstroom: Pro Rege.

KUIPER, B.K. 1995. The church in history. Grand Rapids: CSI.

KUYPER, H.H. s.a. De post acta of nahandelinge van de Nationale Synode van Dordrecht in 1618 en 1619 gehouden. Amsterdam: Höveker \& Wormser.

NEDERDUITSE GEREFORMEERDE KERK. 1998. Handelinge Algemene Sinode. s.l.: s.n.

NEDERDUITSE GEREFORMEERDE KERK. 2004. Die Kerkorde. Wellington: Lux Verbi.BM.

NGK

PKN

kyk NEDERDUITSE GEREFORMEERDE KERK.

kyk PROTESTANTSE KERK IN NEDERLAND.

POLMAN, A.D.R. s.a. Onze Nederlandsche Geloofsbelijdenis. I. Franeker: Wever. 
PONT, A.D. 1981. Historiese agtergronde van ons kerklike reg. I. Pretoria: HAUM.

PROTESTANTSE KERK IN NEDERLAND, 2003. Kerkorde en ordinanties. Zoetermeer: Boekencentrum.

RUTGERS, F.L. 1889. Acta van de Nederlandsche Synoden der $16 \mathrm{e}$ eeuw. Utrecht: Kemink.

SADLER, T.H.N. 1979. Die kerklike tughandeling. Pretoria; NG Kerkboekhandel.

SIZOO, A. s.a. Johannes Calvijn Institutie. III. Delft: Meinema.

SPOELSTRA, B. 1989. Gereformeerde kerkreg en kerkregering. Hammanskraal: Teologiese Skool.

VAN BRUGGEN, J. 1971. Het amen der kerk. Goes: Oosterbaan \& Le Cointre.

VAN DELLEN, I. \& MONSMA, M. 1967. The revised church order commentary. Grand rapids: Zondervan.

VAN DEN HEUVEL, P. 1991. De Hervormde kerkorde. Zoetermeer: Boekencentrum.

VAN ITTERZON, G.P. 1971. Belijnd belijden. Kampen: Kok.

VEENHOF, C. 1969. Volk van God. Amsterdam: Buijten \& Schipperheijn.

VOETIUS, G. 1663. Politica ecclesiastica. I. Amsterdam: Waesberge.

\section{Kernbegrippe:}

belydenisskrifte: gesag ten opsigte van leer hoofrigtings in gereformeerde kerke sedert Dordt

Sinode van Dordrecht: onderskeid tussen geformuleerde leer en vorm

\section{Key concepts:}

creeds: confessional authority main lines in reformed churches since Dordt

Synod of Dordt: distinction between formulated doctrine and their confessions as a whole 